\title{
KEMAS ULANG INFORMASI SEBAGAI SOLUSI ALTERNATIF LITERASI HUKUM WAKAF UANG: SEBUAH STUDI LITERATUR
}

\author{
Aya Yahya Maulana ${ }^{*}$; Danang Dwijo Kangko \\ ${ }^{1}$ Universitas YARSI \\ ${ }^{2}$ Universitas Bina Nusantara \\ *Korespondensi: aya.yahya@yarsi.ac.id
}

\begin{abstract}
ABSTRAK
Wakaf merupakan salah satu instrumen penting yang menopang kemajuan ekonomi umat Islam. Uang sendiri belum banyak diketahui dan diterima masyarakat sebagai salah satu instrumen dalam wakaf. Padahal wakaf uang memiliki potensi yang luar biasa, khususnya bagi Indonesia sebagai negara dengan jumlah penduduk muslim terbesar di dunia. Penelitian ini bertujuan untuk memberikan gambaran pelaksanaan wakaf uang di Indonesia, mengidentifikasi permasalahan yang terjadi, serta memberikan solusi alternatif dari permasalahan tersebut dari sudut kepustakawanan. Penelitian ini merupakan penelitian deskriptif yang dilakukan dengan studi literatur. Penelitian ini menunjukkan bahwa wakaf uang di Indonesia masih jauh dari potensi yang ada. Permasalahan ini terjadi antara lain karena masih minimnya literasi hukum wakaf uang di masyarakat. Untuk mengatasi hal tersebut, salah satu solusi alternatif yang dapat dilakukan adalah dengan melakukan kemas ulang informasi hukum wakaf uang.
\end{abstract}

Kata kunci: Kemas ulang informasi; Literasi hukum; Wakaf uang.

\section{PENDAHULUAN}

Wakaf merupakan salah satu instrumen penting di dalam perkembangan ekonomi umat Islam. Kata wakaf berasal dari bahasa arab "waqf” yang memiliki beberapa arti, yaitu Al-habs yang berarti menahan, al-man'u yang berarti mencegah, as-sukun yang berarti berhenti, dan biasanya diartikan juga sebagai barang yang diwakafkan (mauquf) sehingga barang yang diwakafkan disebut juga wakaf (Kementerian Wakaf, 2007). Adapun secara istilah, wakaf memiliki definisi yang beragam (Zuhaily, 2007) tetapi faktanya Indonesia telah memiliki Undang-Undang Nomer 41 tentang Wakaf, yang di dalamnya mengandung definisi yang mengakomodir pendapat dari berbagai madzhab. Dalam Undang-Undang tersebut wakaf didefinisikan sebagai perbuatan hukum wakif untuk memisahkan dan/atau menyerahkan sebagian harta benda miliknya untuk dimanfaatkan selamanya atau untuk jangka waktu tertentu sesuai dengan kepentingannya guna keperluan ibadah dan/atau kesejahteraan umum menurut syariah.

Harta benda yang dimaksud dalam UU tersebut Pasal 16 ayat (1) dan (2) terdiri dari benda tidak bergerak dan benda bergerak. Benda tidak bergerak sebagaimana disebutkan dalam adalah hak atas tanah, bangunan, tanaman atau benda lainnya yang berada di atas 
Bibliotech : Jurnal Ilmu Perpustakaan dan Informasi, 3 (2) 2018

tanah tersebut, hak milik atas satuan rumah susun, dan benda tidak bergerak lainnya sesuai dengan ketentuan syariah dan peraturan perundang-undangan yang berlaku. Adapun benda bergerak Pasal 16 ayat (3) adalah harta benda yang tidak bisa habis karena dikonsumsi, meliputi:
a. Uang;
b. Logam mulia;
c. Surat berharga;
d. Kendaraan;
e. Hak atas kekayaan intelektual;
f. Hak sewa;
g. Benda bergerak lain sesuai dengan ketentuan syariah dan peraturan perundang- undangan yang berlaku.

Dengan demikian, jelas bahwa uang sah dijadikan harta benda wakaf. Disahkannya uang sebagai harta benda wakaf juga dilandasi-salah satunya — oleh fatwa Majelis Ulama Indonesia pada tahun 2002 tentang wakaf uang yang memutuskan bahwa uang boleh dijadikan harta benda wakaf.

Setelah adanya legitimasi dari UU maka muncullah definisi wakaf uang secara khusus, baik yang dikeluarkan oleh Kementerian Agama maupun BWI (Badan Wakaf Indonesia). Menurut Kementerian Agama dalam Peraturan Menteri Agama Nomor 4 Tahun 2009 Tentang Administrasi Pendaftaran Uang Wakaf Pasal 1 angka 1, wakaf uang adalah perbuatan hukum wakif untuk memisahkan dan/atau menyerahkan sebagian uang miliknya untuk dimanfaatkan selamanya atau untuk jangka waktu tertentu sesuai dengan kepentingannya guna keperluan ibadah dan/atau kesejahteraan umum menurut syariah. Adapun dalam peraturan BWI nomor 1 tahun 2009 tentang Pedoman Pengelolaan dan Pengembangan Harta Benda Wakaf Bergerak Berupa Uang Pasal 1 angka 3, definisi wakaf uang adalah wakaf berupa uang yang dapat dikelola secara produktif, hasilnya dimanfaatkan untuk Mauquf alaih.

Indonesia sebagai negara dengan penduduk Muslim terbesar di dunia telah memiliki aturan khusus tentang wakaf dalam bentuk undang-undang dan lembaga independen yang dibentuk berdasarkan undang-undang tersebut dalam rangka mengembangkan dan memajukan perwakafan di Indonesia. Hal ini tentu membuat Indonesia memiliki potensi menjadi salah satu negara dengan pengelolaan wakaf uang terbesar di dunia. Akan tetapi, sejauh ini pelaksanaan wakaf di Indonesia masih belum terlalu menggembirakan. Berdasarkan hal tersebut, timbul beberapa pertanyaan sebagai berikut: 
Bibliotech : Jurnal Ilmu Perpustakaan dan Informasi, 3 (2) 2018

1. Bagaimana gambaran pelaksanaan wakaf uang di Indonesia dan apa saja permasalahan yang terjadi?

2. Solusi apa yang dapat diberikan dari bidang kepustakawanan untuk mengatasi permasalahan yang ada dalam pelaksanaan wakaf uang di Indonesia?

Kajian tentang hukum wakaf uang, potensi, dan realisasinya telah banyak dilakukan. Akan tetapi, masih sedikit kajian yang menyentuh aspek solusi praktis terhadap kendala dalam pelaksanaan hukum wakaf uang. Selain itu, pembahasan permasalahan ini dari sisi kepustakawanan juga masih sangat jarang. Penelitian ini bertujuan untuk memberikan gambaran pelaksanaan wakaf uang di Indonesia, mengidentifikasi permasalahan yang terjadi, serta memberikan alternatif solusi praktis permasalahan tersebut dari sudut pandang kepustakawanan.

\section{METODE}

Penelitian ini merupakan penelitian deskriptif. Penelitian deskriptif adalah suatu metode dalam meneliti status sekelompok manusia, suatu objek, suatu kondisi, suatu sistem pemikiran, ataupun suatu kelas peristiwa pada masa sekarang (Nazir, 2011). Pengumpulan data dilakukan dengan studi literatur terkait dengan wakaf khususnya wakaf uang di Indonesia baik dari media cetak maupun elektronik. Definisi studi literatur (pustaka) menurut Sugiyono (2012) adalah kajian teoritis, referensi serta literatur ilmiah lainnya yang berkaitan dengan budaya, nilai dan norma yang berkembang pada situasi sosial yang diteliti. Analisis dan interpretasi dilakukan terhadap data yang terkumpul kemudian dituangkan ke dalam hasil dan pembahasan kajian. Hasil dan pembahasan kajian inilah yang menjadi dasar dari penyusunan kesimpulan.

\section{HASIL DAN PEMBAHASAN}

Indonesia selalu diunggulkan dalam hal potensi di antara negara dengan mayoritas penduduk muslim lainnya, tidak lain karena predikat jumlah penduduk muslim terbesar di dunia. Hal ini pastinya berimbas pada besarnya potensi di bidang ekonomi tidak terkecuali dengan wakaf. Jumlah aset wakaf tanah saja di Indonesia tercatat sebanyak 366.595 lokasi dengan luas 2.686.536.565,68 $\mathrm{M}^{2}$ (Nafis, 2012). Sungguh bukan nilai yang kecil. Bayangkan jika satu meter tanah dihargai dengan nilai seratus ribu rupiah saja, terbayang betapa besar potensi yang tersedia.

Lalu bagaimana dengan potensi wakaf uang di Indonesia. Berbicara masalah potensi, jika wakaf uang dapat diimplementasikan dengan baik maka ada dana potensial yang sangat 
besar yang bisa dimanfaatkan untuk program-program pemberdayaan dan kesejahteraan umat. Nafis (2012) menjelaskan bahwa jika 20 juta umat muslim Indonesia mau mengumpulkan wakaf uang senilai Rp 100 ribu setiap bulannya, maka dana yang terkumpul berjumlah Rp 24 triliun setiap tahun. Jika 50 juta orang yang berwakaf, maka setiap tahun akan terkumpul dana wakaf sebesar Rp 60 triliun. Bahkan jika 1 juta saja maka akan diperoleh Rp 1,2 triliun per tahun. Sungguh suatu potensi yang luar biasa.

Adapun menurut Nasution (2005), potensi penghimpunan wakaf uang di Indonesia yang dapat dihimpun sebesar Rp 3 (tiga) triliun rupiah pertahun. Perhitungan ini didapat dengan asumsi bahwa jumlah muslim kelas menengah diperkirakan sebesar 10 juta jiwa dengan rata-rata penghasilan perbulan antara $\mathrm{Rp}$ 500.000,- (lima ratus ribu rupiah) sampai dengan Rp 10.000.000,00 (sepuluh juta rupiah), kemudian nilai sertifikat wakaf uang dibagi besarannya mulai Rp 5.000.- sampai dengan Rp 100.000, maka dapat dibuat perhitungan seperti Tabel 1 dibawah ini:

Tabel 1. Hitungan Potensi Wakaf Uang

\begin{tabular}{|c|c|c|c|c|}
\hline $\begin{array}{c}\text { Tingkat } \\
\text { Penghasilan/bulan }\end{array}$ & $\begin{array}{c}\text { Jumlah } \\
\text { Muslim }\end{array}$ & $\begin{array}{c}\text { Tarif } \\
\text { Wakaf/bulan }\end{array}$ & $\begin{array}{c}\text { Potensi Wakaf } \\
\text { Tunai/bulan }\end{array}$ & $\begin{array}{c}\text { Potensi Wakaf } \\
\text { Tunai/tahun }\end{array}$ \\
\hline Rp 500.000 & 4 juta & Rp. 5.000 & Rp. 20 Milyar & Rp 240 Milyar \\
\hline Rp 1 juta - Rp 2 juta & 3 juta & Rp 10.000 & Rp 30 Milyar & Rp 360 Milyar \\
\hline Rp 2 juta - 5 juta & 2 juta & Rp 50.000 & Rp 100 Milyar & Rp 1,2 Triliun \\
\hline Rp 5 juta - 10 juta & 1 juta & Rp 100.000 & Rp 100 Milyar & Rp 1,2 Triliun \\
\hline \multicolumn{7}{|c}{ Total } & Rp 3 Triliun \\
\hline
\end{tabular}

Sumber: Nasution (2005)

Selain hitungan potensi yang disampaikan oleh Nasution pada Tabel 1, Imam Teguh Saptono (Badan Wakaf Indonesia, 2019) selaku wakil Ketua BWI memiliki hitungan potensi yang berbeda. Ia menyatakan bahwa metrik potensi wakaf uang di Indonesia mencapai Rp.77 triliun per tahun. Angka tersebut didapat dengan cara menghitung jumlah masyarakat Indonesia dengan status menengah ke atas yang berjumlah 116 juta jiwa dikurangi sekitar 23 persen masyarakat yang dianggap apatis. Jumlah setelah dikurangidengan rata-rata penghasilan 10 Dollar per hari-kemudian dikalikan 2,5 persen untuk wakaf. 
Bibliotech : Jurnal Ilmu Perpustakaan dan Informasi, 3 (2) 2018

Jika melihat ke belakang, sebenarnya praktik wakaf uang di Indonesia sudah dimulai setelah keluarnya fatwa tentang Wakaf Uang oleh Majelis Ulama Indonesia (MUI) pada tahun 2002. Sejak itulah terdapat beberapa lembaga yang mulai mengimplementasikan fatwa tersebut dengan melakukan penghimpunan wakaf uang, karena secara syariat, lembaga-lembaga tersebut telah mendapatkan legitimasi dari fatwa MUI. Fatwa tersebut disusul dengan terbitnya UU pada tahun 2004. Puncaknya adalah pencanangan Gerakan Nasional Wakaf Uang pada tanggal 8 Januari 2010 oleh Presiden Susilo Bambang Yudhoyono (Husna, 2010).

Akan tetapi yang perlu diperhatikan, realisasinya sejak diluncurkan sampai tahun 2015 - dari data yang didapatkan dari Badan Wakaf Indonesia-berdasarkan laporan yang terkumpul dari 52 (lima puluh dua) nazhir, telah terkumpul wakaf uang sebesar Rp. 185.060.582.368 (seratus delapan puluh lima miliar enam puluh juta lima ratus delapan puluh dua ribu tiga ratus enam puluh delapan rupiah). Sedangkan jumlah nazhir wakaf uang sampai dengan tahun 2015 berjumlah 131 (seratus tiga puluh satu) nazhir (Badan Wakaf Indonesia, 2015). Rendahnya realisasi wakaf uang ini diamini oleh Imam Teguh Saptono. Ia menyatakan bahwa perkembangan wakaf uang di Indonesia sejak pertama kali dicetuskan di tahun 2010, baru sekitar Rp199 miliar (Badan Wakaf Indonesia, 2019). Jika kita hitung pencapaian wakaf uang tahun 2015 sebesar 185 miliar rupiah terhadap potensi yang disebutkan oleh Nasution sebesar 3 triliun per tahun, maka pencapaian tersebut hanya berkisar $6 \%$.

Membahas tentang permasalahan yang menghambat berkembangnya praktik wakaf uang, ketua divisi Humas, Sosialisasi, dan Literasi (Husoli) Badan Wakaf Indonesia, Atabik Luthfi, mengungkapkan bahwa kendala sosialisasi hukum wakaf tunai, khususnya di pedesaan disebabkan karena persepsi yang ada di masyarakat yang masih beranggapan wakaf adalah harta tak bergerak seperti tanah, masjid, kuburan (Fadhilah \& Aminah, 2018). Persepsi ini tertanam di masyarakat sudah sejak lama dan sulit untuk diubah. Selain dari adanya persepsi yang menjadi hambatan, perkembangan wakaf uang di Indonesia terkendala dengan literasi masyarakat mengenai wakaf yang masih sangat minim (Badan Wakaf Indonesia, 2019). Meskipun tidak dipungkiri bahwa dari sisi sosialisasi dipandang belum maksimal sejak adanya Undang-Undang tentang Wakaf (Hidayat, 2019).

Memang perlu diakui bahwa Badan Wakaf Indonesia sudah melakukan banyak cara dalam mensosialisasikan wakaf uang (Harahap, 2013). Akan tetapi, seberapa efektif usaha yang dilakukan belum bisa dikatakan memuaskan jika dilihat dari hasil yang diperoleh. 
Bibliotech : Jurnal Ilmu Perpustakaan dan Informasi, 3 (2) 2018

Apalagi membaca informasi hukum seperti Undang-Undang yang biasanya terkesan kaku sehingga membuat masyarakat kurang tertarik.

Dengan demikian dapat diketahui bahwa sumber permasalahan yang terjadi ada pada masyarakat dan regulator serta operator wakaf itu sendiri. Masyarakat mengalami permasalahan terkait persepsi tentang hukum wakaf uang yang kurang tepat. Selain itu, pengetahuan atau keterampilan (literasi) dalam bidang atau aktivitas wakaf uang di masyarakat masih rendah. Di sisi regulator dan operator wakaf, sosialisasi telah coba dilakukan akan tetapi hal tersebut belum maksimal. Oleh karena itu dibutuhkan solusi alternatif agar penyampaian informasi hukum wakaf uang tidak terkesan kaku dan lebih menarik.

Kemas ulang informasi adalah proses menyeleksi, menganalisis, dan mengonsolidasi informasi dalam bentuk yang lebih sesuai untuk digunakan oleh pengguna perpustakaan (Dongardive, 2013). Kegiatan ini meliputi kegiatan analisis, sintesis, penyuntingan, penerjemahan, dan alih format media serta simbol (Widyawan, 2012). Menurut Tupan dan Nashihuddin (2015), kemas ulang informasi dilakukan dengan tujuan untuk:

a. Menyajikan informasi dalam bentuk kemasan yang lebih menarik, dapat diterima pengguna secara langsung, dan mudah dimengerti isinya.

b. Menyediakan informasi dengan cara meringkas dan mensintesis data atau penelitian yang sesuai dengan kebutuhan pengguna.

c. Menyediakan sarana dan panduan untuk menyusun kemasan informasi.

d. Mengumpulkan informasi mutakhir dari berbagai sumber baik dalam maupun luar negeri.

e. Mengulas atau meninjau berbagai literatur dan dokumen yang telah dikumpulkan.

Beberapa penelitian tentang kemas ulang informasi menunjukkan bahwa kemas ulang informasi dapat digunakan untuk menyampaikan informasi dengan baik. Penelitian Anggraeni \& Arfa (2017) menunjukkan bahwa penggunaan kemas ulang informasi berupa infografis efektif sebagai media pembelajaran mata pelajaran IPA siswa kelas VII di SMP N 1 Tembarak. Penelitian Sae \& Islaminingsih (2016) menunjukkan bahwa produk kemas ulang informasi dokudrama ber-subtittle efektif sebagai sarana pembelajaran bagi pemustaka tunarungu. Sedangkan penelitian Maryati \& Yoganingrum (2015) memperlihatkan bagaimana pengemasan informasi ke dalam bentuk sebuah film seperti video animasi 3 dimensi dapat membantu mengatasi permasalahan rendahnya literasi informasi di wilayah pesisir dan kepulauan Indonesia. 


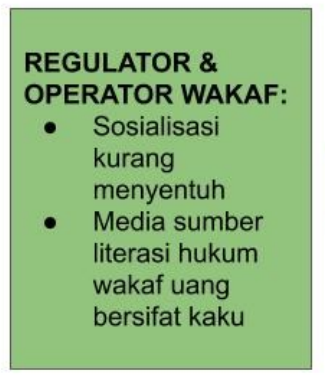

\section{Kemas Ulang Informasi Hukum Wakaf Uang}

MASYARAKAT:

- Persepsi tentang hukum wakaf uang

- Literasi hukum wakaf uang

\section{Gambar 1. Kemas Ulang Informasi untuk Literasi hukum wakaf uang}

Kemas ulang informasi dapat menjadi solusi agar penyampaian informasi hukum wakaf uang lebih mudah diterima oleh masyarakat, lihat Gambar 1. Regulator dan operator wakaf dapat melakukan kemas ulang informasi terkait hukum wakaf uang sebagai sarana untuk meningkatkan literasi hukum wakaf uang di masyarakat. Dengan demikian, diharapkan persepsi masyarakat tentang hukum wakaf uang berubah lebih baik dan realisasi penerimaan wakaf uang di Indonesia meningkat.

\section{KESIMPULAN}

Berdasarkan studi literatur yang telah dilakukan, realisasi wakaf sampai saat ini sejak dicanangkan belum menunjukkan hasil yang maksimal. Pencapaian wakaf uang tahun 2015 hanya sebesar 185 miliar rupiah, sedangkan potensinya sebesar 3 triliun rupiah per tahun. Pencapaian tersebut hanya berkisar $6 \%$ dari potensi yang diharapkan.

Adapun permasalahan yang dihadapi dari sisi masyarakat adalah persepsi tentang hukum wakaf uang yang kurang tepat. Selain itu, pengetahuan atau keterampilan (literasi) dalam bidang atau aktivitas wakaf uang masih rendah. Sedangkan dari sisi regulator dan operator, sosialisasi telah coba dilakukan akan tetapi hal tersebut belum maksimal.

Alternatif solusi yang dicanangkan adalah dengan melakukan kemas ulang informasi. Beberapa penelitian tentang kemas ulang informasi menunjukkan bahwa upaya tersebut dapat digunakan untuk menyampaikan informasi dengan baik. Hal ini bisa menjadi solusi agar penyampaian informasi hukum wakaf uang lebih mudah diterima oleh masyarakat, juga sebagai sarana untuk meningkatkan literasi hukum wakaf uang di masyarakat. 
Bibliotech : Jurnal Ilmu Perpustakaan dan Informasi, 3 (2) 2018

Ada banyak alternatif pilihan jenis produk kemas ulang yang dapat dipilih oleh regulator dan operator wakaf. Setiap jenis produk kemas ulang tersebut memiliki kelebihan masing-masing. Penelitian mengenai pemilihan jenis produk kemas ulang dan prosesnya disarankan untuk dilakukan lebih lanjut karena hal tersebut belum termasuk dalam cakupan penelitian ini.

\section{DAFTAR PUSTAKA}

Anggraeni, R. \& Arfa, M. (2017). "Efektivitas Produk Kemas Ulang Informasi Berupa Infografis Sebagai Media Pembelajaran Mata Pelajaran IPA (Studi Eksperimen Pada Siswa Kelas VII di SMP N 1 Tembarak Kabupaten Temanggung”. Jurnal Ilmu Perpustakaan, $6(1)$ 241-250. https://ejournal3.undip.ac.id/index.php/jip/article/view/23082

Badan Wakaf Indonesia. (2009). Peraturan Badan Wakaf Indonesia Nomor 1 Tentang Pedoman Pengelolaan dan Pengembangan Harta Benda Wakaf Bergerak Berupa Uang.

Badan Wakaf Indonesia. (2015). Laporan Gerakan Wakaf Uang tahun 2015.

Badan Wakaf Indonesia. (2019). Wakaf Indonesia Simpan Potensi Rp 77 Triliun. Diakses dari https://www.badanwakafindonesia.com/post/makanan-penutup-ala-tuan-guruimam-teguh-saptono Pada tanggal 2 Juni 2019.

Dongardive, P. (2013). "Information Repackaging in Library Services". International Journal of Science and Research (IJSR), 2 (11), 204-209. https://www.ijsr.net/archive/v2i11/MDIwMTM0MDM=.pdf

Fadhilah \& Aminah. (2018). Persepsi Jadi Kendala Sosialisasi Wakaf Tunai. Diakses dari https://www.republika.co.id/berita/dunia-islam/wakaf/18/10/16/pgp246384-persepsijadi-kendala-sosialisasi-wakaf-tunai Pada tanggal 3 Juni 2019.

Harahap, F. (2013). Strategi Public Relations Badan Wakaf Indonesia Dalam Mensosialisasikan Wakaf Tunai. Diakses dari http://repository.uinjkt.ac.id/dspace/bitstream/123456789/27738/1/FATMAWATI\%2 OHARAHAP-FDK.pdf

Hidayat. (2019). Tantangan dan Prospek Wakaf Uang. Diakses dari https://www.hukumonline.com/berita/baca/lt5cf3edb62c275/tantangan-dan-prospekwakaf-uang/ Pada tanggal 10 Juni 2019. 
Bibliotech : Jurnal Ilmu Perpustakaan dan Informasi, 3 (2) 2018

Husna, S. (2010). Masalah Wakaf Uang. Diakses dari https://bwi.or.id/index.php/en/publikasi/news/604-masalah-wakaf-uang.html Pada tanggal 20 Juni 2019.

Kementerian Agama Republik Indonesia. (2009). Peraturan Menteri Agama Nomor 4 Tentang Administrasi Pendaftaran Uang Wakaf.

Maryati, I. \& Yoganingrum, A. (2015). "Information Packaging Process for Solving The Lack of Information Literacy in Coastal and Small Island Areas in Indonesia". Paper of The General Conference Congress of Southeast Asian Librarians (CONSAL) XVI Bangkok - Thailand, 11 - 13 June.

Nafis, C. (2012). Aplikasi Wakaf Uang di Indonesia. Diakses dari https://bwi.or.id/index.php/publikasi/artikel/974-aplikasi-wakaf-uang-diindonesia.html?lang=in Pada tanggal 25 Maret 2019.

Nasution, M. E. (2005). 'Wakaf Tunai dan Sektor Volunteer'. Wakaf Tunai Inovasi Finansial Islam; Peluang dan Tantangan Dalam Mewujudkan Kesejahteraan Umat. Jakarta: PKTTI-UI.

Nazir, M. (2011). Metode penelitian. Ghalia Indonesia: Bogor

Republik Indonesia. (2004). Undang-Undang Nomor 41 Tentang Wakaf.

Sae, M.P. \& Islaminingsih, R.N. (2016). "Efektifitas Produk Kemas Ulang Informasi Dokudrama Bersubtittle sebagai Sarana Pembelajaran bagi Pemustaka Tunarungu". Jurnal Ilmu Perpustakaan, 5(3), 281-290. https://ejournal3.undip.ac.id/index.php/jip/article/view/15253

Sugiyono. (2012). Metode penelitian kombinasi. Alfabeta: Bandung

Tupan \& Nashihuddin, W. (2015). "Kemas ulang informasi untuk pemenuhan kebutuhan informasi usaha kecil menengah: tinjauan analisis di PDII-LIPI”. BACA: Jurnal $\begin{array}{llll}\text { Dokumentasi dan } \quad \text { Informasi, } & \text { 36(2), }\end{array}$ http://jurnalbaca.pdii.lipi.go.id/index.php/baca/article/view/163

Widyawan, R. (2012). “Kemas Ulang Informasi: Membuat Informasi Menjadi Lebih Seksi”. ( http://digilib.undip.ac.id/v2/2012/05/07/kemas-ulang-informasi-membuat-informasimejadi-lebih-seksi/, diakses 2 Juni 2019).

Zuhaily, W. (2007). Al-fiqh al-Islamy wa Adillatuhu. Damaskus: Dar Fikr. 
Bibliotech : Jurnal Ilmu Perpustakaan dan Informasi, 3 (2) 2018 